\section{Tima Silnetures}

ON THA

\section{PHYSIOLOGY OF THE EMOTIONS. \\ Demivared at King's College,}

Bт F. W. MOTT, M.D., F.R.C.P., F.R.S.,

PATHOLOGIST, LONDON COUNTY COUNCIL ASYLUMS; PHYSICIAN TO CHARING CROSS HOSPITAL.

\section{IECTURE II.}

The Path of Pain Impolsis in the Spinat Cord. Somify tanght that the grey matter is aesthesodic and the white matter kinesodic. A condition known as sj ringomyelis, in which the grey matter is destroyed and the white matter uninjared, is characterized by a condition of sensory dissoclation. The patient feels tactile sensations, but no longer feels pain, or heat and cold. Sherrington has ahown that the loppulse of painful impressions coming from one half of the body leaves the giey matter and passes up the lateral colamn of both sides, rather more on the opposite. The painful stimnlas is transmitted to the brain, but there is no certain evidence to show that pain is represented in any part of the cortex.

Painful sensations, together with all afferent sensory stimull, meet in the optic thalamus, the principal function of which is that of a censory relay station to the cortex. This mass of grey matter, including the external and internal geniculate bodies and pulvinar, sends afferent radiations to all parts of the cerebral cortex, but particalarly to the projecition centres about the primary fissures It contains two forms of cells, large cells like those of the anterior horn of the spinal cord and the motor ares of the cortex, and smaller cells. These large cells are in all probability motor in function, and control the subconscious involuntary, instincfive, automstic mimle reflexes of gesture, physiognomical expression, and of primitive vocalization. The evidence in favour of this is that experimental lesions in animsls and spontaneous lesions in man invariably produce some degree of anacsthesla on the side opposite the lesion. Irritative lesions of the thalamus are frequent]y associated with geverd pain in the opposite half of the body. It is a well known fact, first deserlbed by Sir Charles Bell that in old cases of cortical hemiplegla the face on the diseased side can only be imperfectly moved by the will, yet if the patlent, under the in fluence of the emotions, laugbs or cries this side of the face is more strongly contracted than the non-paretic side. In lesions of the thalamue, on the other hand, the opposite is frequently observed. The pattent, on the one hand, can voluntarily move the paretlc side of the face well in al directions, as in showing the teeth, volantary laughing, ttc ; on the nther hand, in emotional expressional movements this side of the face is immovable. According to that very reliable observer, von Monakow, thls con dition is not met with in any other cerebral lesion; therefore, al though it does not occur in everg lesion of the optic thalamus, yet the fact that it does not occur in other cerebral lesions indicates that some part of the thalamus 18 assoclated with these reflex mimetic movements. Monakow, moreover, cites cases which seem to show that It Is possible " that secretory, vasomotor and other tracts of fibres in connexion with the sympathetic nervous system have an abundant representation in the thalamus opticas."

Bat let us return to pain, and for argament sake say that pain is produced by a strong excitation transmitted by the grey matter and lateral colnmns of the spinal cord to the thalamus; here the feeling of pain is produced, but this is always associated with perceptual cortical feeling of locslization and cause, with secondary assoclations of time and space. If pain per se wera represented in the cortex, then it should be continually revived in memory with the re-representation, but pain is forgotten 88 soon as it is over, and what we recollect are those intellectual perceptions which will enab!e us. to avoid it In the fature.

Stlmulation of the cortex of the central convolutions has been performed without ansesthetics in man (Dana) the only effect was a slight numbness and tingliug in the extremities, fingers, thumb, etc., not amounting to paln. The brain can be cut without causing psin. Stimulation of the thalami in animals, in contradistincticn to the cortex glves rise to manilestations of pain. Paln is unknown as an aura in cortical epilepey, and no region of the cortex has been proved beyond doubt to be associated with pain, although it has been asserted that the gy rus fornlcatos is a centre for pain.

Sherrington has shown that in a splnal animal the pain reflex is prepotent. Take, for exsmple, the reflexes which engage all the muscles of the hind limb in purposive movements of a neeful character; if a reflex, such as scratching, is set up in the right. leg, to remove a stimulus resembling a parasite among the hairs of the front of the body, and, while this scratching-1s.proceeding; a painful stimulus (llke a thorn) is applied to the pad of the left loot, a flexor withdrawal occurs, accompanled by a replacement of the right foot to the ground to act as a support. Fisperiments show that the sexual reflex in the lower animals - for example, frogs and tortolses, etc-ls even more potent than pain reflexes, and Sherrington rightly affirms " that refleres arising in species of receptors which, considered as sense organs, provoke strongly affective sensations, caeteris paribus, prevall over reflexes of other species when in competition with them for the dise of the final* common path."

If now we exsmine the effects of painful atimulation of the skin in a deserebrate animal, in which therefore a wider conjunction of reflex arcs is left than in the spinal anlmal, number of refleres are obtained which Sherrington terms " pseudo-sffective," because the neural mechanism for the percaption of pain is cat off from its connexion with the receptor ; but it is still in connexion with a purposive lostinctive reflex motor mechanism of offence and defence, the action of which is usually considered as the outward expres sion of the inward affective feeling, and it may be assumed that had the brain been present the feeling would have occurred. Such a decerebrate animal; when the sciatic nerve is stimulated, exhlbits. movements indlcative of offence and defence, forward cyclic movements, as in progression, turning of the head toward the part excited, opening of the month, retraction of the lips, movements of the jow os in snapping, movements of vibrissae, lowering of the head, dilatation of the pupils, vocalization avgry in tone (sometimes plaintive, sometimes snarling), and with these a passing increase of arterial blood pressure. These movements are ineffective and of brief duration $\dagger$ possibly because they are deprived of the perceptual reinforcement which the brain gives. Sherring ton proceeded to ascertain how these pain reflexes can be abolished, in order to establish the probable path: of pain reflexes in the cord. The method Woodward and he adopted was to compare by means of the above reaction the effect of two stimali symmetrically but successively applied on opposite sides of the body after a semizection of the spinal cord or other lesion of the spinal cord headward of the nerve path stimnlated. He concludes that each lateral colnmn conveys impulses from both halves of the body, and somewhat preponderantly from the crossed ball; and this is true for these arcs, whether they be traced from skin, muscles, or viscers.

Goltz, by a long series of carefal and judiciousjy planned experiments, was able to remove the whole of the cerebral hemlspheres and a large part of the basal ganglia from a dog in successive operations, and the animal by patient and careful feeding was kept alive many months, and valuable observations on a decerebrate animal were made. Its bebaviour as compared with his own normal dog is a most valuable psychophysiological study, and I will briefly describe the more important festures of thls comparison. The animal would lle curled up like a normal dog, it could be aroued by the lond blowing of a horn, and by blowing through a tabe a current of alr on to its skin, when it would raise itself on Its four legs and shske itself. If the animal had been ronsed by the blast of the horn it would put its paw up to its ear as if something anpleasant had happened. When the animal was removed from the pan, as 16 was every day, to be led, it growled, snapped, and snarled llke an

* Sherrington uses this term for nervea to muscles which are mploved for the performance of reflex actions under the influenco of different stimuli.

t More probably the brief duration is due to the fact that. if - 70 regard the whole nervous system as an accumulator of energs, the of the store of energy. 
angry brute, and resisted and struggled to be free and return to Its cage; it showed, in fact, exactly the same signs of anger as the decerebrated dog whose solatic nerve was atlmulated in Sherrington's experiment: lowerIng of the head, bristling of the hair, retraction of the ears, and growling, biting, and snapplng. Although removal from the cage every day meant to the animal appeasement of hunger, yet this animal every day for eighteen months, until the day of its death under chloroform, gave the same instinctive sign of anger, and never joy, fear, or affection. Golty compared the behaviour of this animal with the behavlour of his own animal, who would allow him to pull his tall and tread on his foot showing, however, by his expression that he felt it painful but he tolerated it and controlled his feelings because of affection for hls master. The decerebrate bitch, on the contrary, made no distinction between the stranger and the man who had fed her every day. She had no memory,

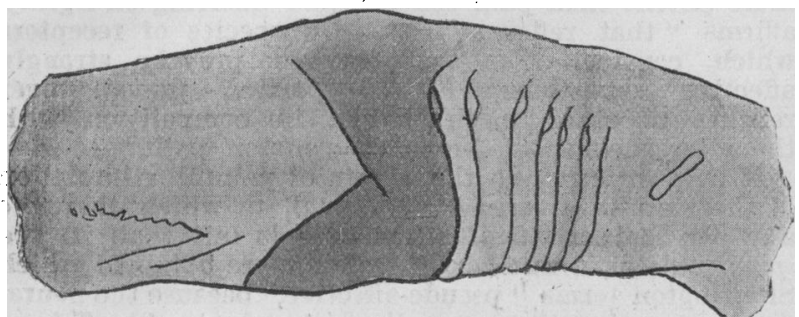

Fig. 1.-The muscles of a shark supplied by facial nerve. After Ruge.

but still possessed desires and instinctive reactions. When hungry especially, like the wild animals in the Zoologlcal Gardens, she performed contlnuous pacing movements of locomotion In one direction from right to leit, or the contrary; moreover, she would place her two forepaws on the front of the cage, standIng on her hind legs. She could maintain her position on the four limbs on s smooth and sloping surface, and defaecated and urinated Ilke a normal bitch. The expression of the dog was entirely devold of intelligence, and It did not wag its tall, nor did it ever show slgns while asleep of dreaming like other dogs. When fed the lood was : placed near Its murale; it then mastlcated and swallowed it ltke a normal dog. An interesting experiment was made by Goltz in relation to the emotion of disgust. Pieces of meat were soaked In a solution of quinine and given to the animal; it relused to eat the meat. The same pleces were given to the normal dog; it - wagged its tall, pulled a lace, and looked to Its master as much as to sey, Well, this is un. kind of you to glve me this! I don't like It, but to obllge you I will swallow it, which he did upon encouragement. Not even hunger would make the dog without a brain swallow

the bltter meat. Now this intere ting fact supports Bichet's vlew that bitter and acrld sobstances which are unpleasant are as a general rule poisonous or noxlous, whereas gweet tasting things for which we have a gust (goît) are pleasant and beneficial. So that disgust (dégoût) Is protectlve to the alimentary canal and the vital bodily organs. just as pain protects the external surface of the body. This animal ceased to have oestral periods and never showed the slightest sexual desires. The animal was deprived, however, not only of the cerebral cortex, but also of the basal ganglia, the corpus strlatum and the optlc thalamus. How it would have behaved had it been possible to destroy the cortex leaving these structures we do not know, but the experiments of Nothnagel, Bechterew and many others rather point to these structures being verg important in relation to the emotions, and recently Pagano bag published a number of experiments on adult and newborn dogs which I will briefly relate, although I am of oplnion that the experiment of injecting fluids grch as curare Into the basal ganglla, even though controlled by simultaneous coloration by $a$ dye so that the extent of the effect of the Irritant can be gauged on post-mortem examinatlon, is not altogether reliable. This experimenter claims to have demonstrated that excitation of the caudate nucleas and of the optic thalamus provokes in adult dogs movements of expression distinctly attributable to determined emotionsl states accompanied by visceral phenomens. It was, however, important to demonstrate that there was a real functional autonomy; he therefore exclted. the candate nucleus in newborn animals. From his experiments he concludes that in the basal ganglia are found at birth the physiologlcal pre-organized mechanisms of emotional reactions. The cerebral cortex not being functional at birth 18 , therefore, not Indispensable for these emotions. He concludes also that the superiar psychical centres which are superimposed on the lower centres are only a new source of stimulus for primordial expression, but at the same time the orlgin of secondary modificatlons of emotional expresslons. He injects 0.1 c.cm, of 2 per cent. solution of curare

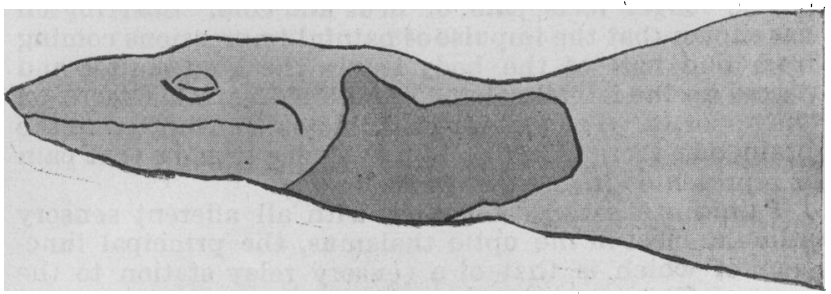

Fig. 2.-The muscles of a reptile supplied by facial nerve. After Ruge

coloured with thionine into various portions of the caudate nucleus. The results obtained are as follows: Excitation of the anterior third and of the middle third of the caudate nucleus, especially in their inner half, provokes the emotional phenomena of fear. They are characterized by the attitude of the body, the pbysiognomy, the cardiac and resplratory phenomena, intestinal and vesical, the state of the pupils, and menacing nolses which exagge. rate considerably these manifestations of terror. Excitation of the anterior extremity of the candate nucleus produces phenomena of psycho-motor agitition of the same kind, and expresses a mingling of the two emotions fear and anger. Excitation of the posterior portion provokes manifestations of anger. Excitation of the anterior third produces erection of the penis almost as strongly as atimulation of the lumbar centre.

Sherrington has performed some notable experiments which show that an animal whose brain has been cut off in its connexion from the heart and viscera generally, stlll exhiblts joy and sorrow, anger and fear, disgust and serual instinct. He divided the eplnal cord in $a \mathrm{dog}$ In the lower cervical region, and when the animal had aufficlently recovered he cut both pneumogastric nerves. In this way the brain was cut off from any afferent impresslons from the viscera, jet the animal showed joy at seeing the attendant who fed him, anger at a stranger, and fear and sorrow when scolded. One animal only 9 weeks old, kennel.fed, was thus operated upon, and when given milk in whlch pleces of dog flesh had been placed, absolutely refused to touch this flesh under any circumstances and showed marked gigns of disgust. Sherrington lays particular stress on this experiment as proving that "even the primitive emotions seem to involve perception, seem little other than sense perceptions richly suffased with affective tone." Of course Sherrington himself is aware that these experiments are not conclusive, for although the animals may have expressed emotion in their faclal expression and attitude approprlate to the excliting cause, although the viscero-vascular and much of the muscular expression was cut off Irom the sensorium, yet we have no means of knowlng the subjective feeling of the animsl, and " 8 small but notable fraction of the latter-namely, the faclal, still remained open to react in the centres with whlch consciougness is colligate." Again, Lloyd Morgan, in con- 
nexion with this experiment, states: "The avenues of connexlon were (only) closed alter the motor and visceral effects had played their part in the genesls of the emotion on the hypothesis that the emotion is thus generated. Although new presentative data of this type were thas excluded, their representative alter-effects were not thus excluded." In reply to this criticlom, Sherrington remarks :

But it is noteworthy that one of the dogs under observation had been thus experimented upon when only 9 weeks old Disgust for dog's flesh could hardly arise from the experience of nine weeks of puppyhood in the kennel.

Now this aversion to dog's flesh was due to olfactory impresslons, and that "dog will not eat dog" may, in the long procession of the ages, have led to the establisbment of a preorganlzed mechanism by whlch disgust at dog's flesh might occur reflexly in the medulla; the paths of smell and taste were still open, and the only means the dog had of showing aversion it exhlbited. We see that Goltz's dog exhlblted disgust at meat soaked in quinine, although the gustatory cortical centres could not have been acting.

Newborn animals are excited to the complex act of

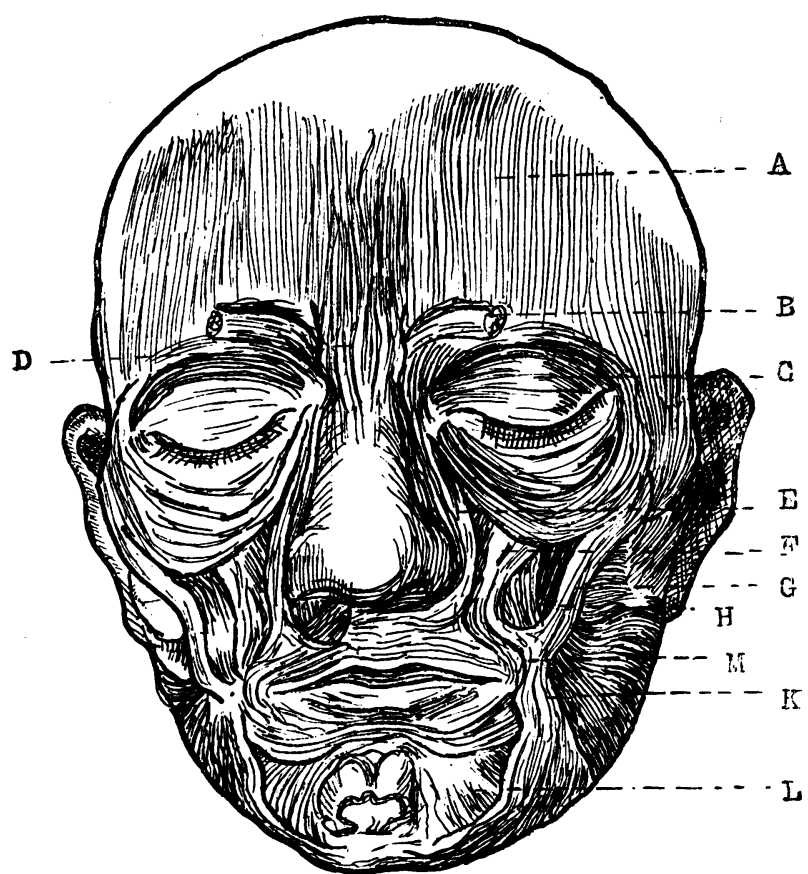

Fig. 4.-Diagram of muscles of face, from Sir C. Bell. A, Occipitofronttilis. B, Corrugator supercilil. c, Orbicularis palpebrarum D. Pyramidalis nasi. E, Levator labii superioris alaeque. F, Levator labil proprius. G, Zygomatic. H, Malaris. K, Triangu-
laris oris. L, Quadratus menti. M, Risorius.

sucking and pressing forward the forelimbs, and it is said that the stimulus 18 smell, for such are not performed is the olfactory nerves of a puppy are destroyed. Moreover anencephalous monsters cry and show signs of pain and desire for food, and they are capable of the complex acts of sucking and crying without any cerebrum. There must, therefore, be a preorganlzed mechanism for crying and sucking In the bage of the brain. In mammals the lips and the muscles of the llps have been primarily developed for the purpose of sucking, the nostrils and the muscles that act on the nostrils for the purpose of breathing during the act of sucking. The senses of the young mammal requlre to be educated in order to be able to adapt Itself to its environment, consequently it is for a time helpless and dependent upon its mother for nutrition and protection. But the mother must leave it to seek food. consequently the offspring requires a means of calling for her help to satiofy the needs of hunger or for protection; thereby has been evolved a preorganized nervous mechanism for crying which involves the integration of even a larger number of neurones than the act of sucking. Now, Sir Oharles Bell ohowed that the respiratory nerves form a superadded system introduced in the higher animals in correspondence with changes of structure which the organ of breathing undergoes in the course of development in animals. Not until we arrive at the fishes, the lowest of the vertebrates, do we find the mouth connected with the organ of respiration. In the reptiles nostrils appear, and in the mammals lips, and for the better adaptation to environment as we ascend the scale of vertebrates we ind a progressive reciprocal simultanelty of develonment in the clrculatory, nutritive, and resplratory systems and the neural mechanism for their assoclated action. As Bell says, there is a remarkable consent between the muscles of deglutition and respiration.

Our present knowledge of comparative anatomy of the nervous system tells us the truth of Bell's remarkable foresight and philosophic deductions. Dr. Arlens Kappers In a most interesting paper on the phylogenetic disposltion of the motor cranlal nuclei and the structure of the antonomous sympathetic system, points out that in fishes the seventh nerve innervates the constrictors and a muscle termed the "adductor mandibuli," whlch we find again in the higher animals as the posterlor belly of the digastric. The constrictor group of mufles is anp. plied by a group of viscero-motor cells which acquire

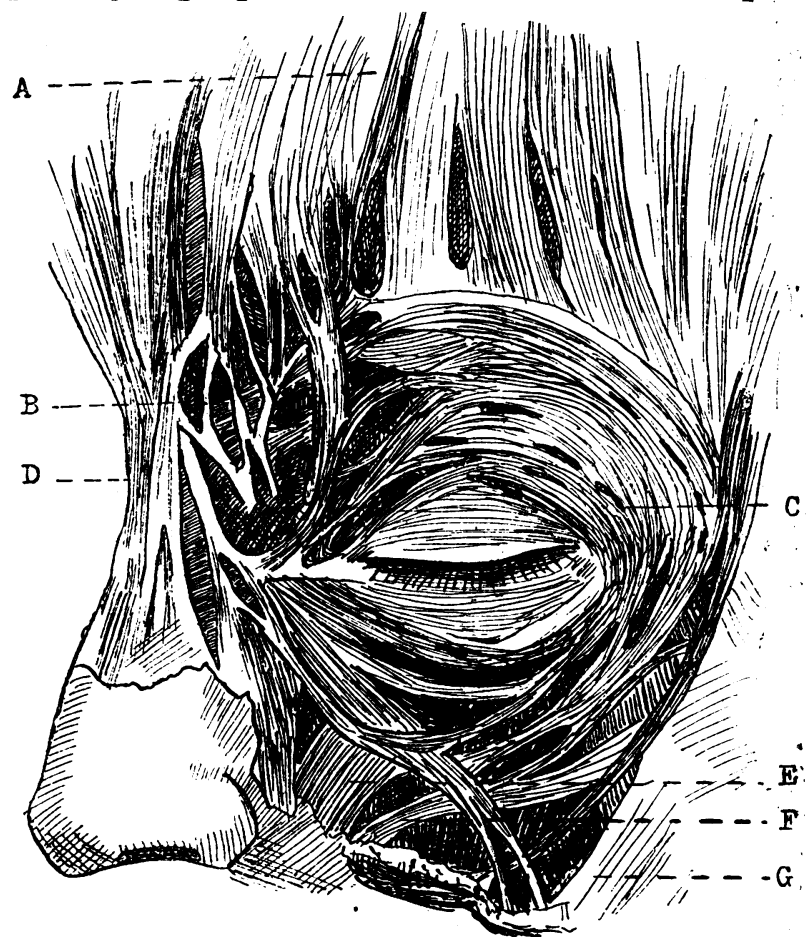

Tig. 5.-Diagram from Henle. A, Occipito-frontalis. B, Corrugator supercilii. c, Orbicularis palpebrarum. D, Pyramidalis nasi. F, Levator labii superioris alaeque. F, Levator labii proprius. G, Zygomatic.

as we ascend the animal scale a secondary somatic importance. The great sphincter of the neck in reptlles and birds owing to the more complex arrangement of respiration is developed in mammals into the great group of muscles of the neck and face (vide Figs. 1, 2 3). It is therefore the constrictor group which not only increases, but also becomes strongly gomatic, in proportion to its function taking part in the life of external relation and less in the life of Internal relation. We also see how intimately deglutition is phylogenetically associated with the muscles which express the emotions. As progressive development occurs the nucleus of those facial muscles of expression (phylogenetically of visceral origln) comes more and more nnder the influence of the will by innervation currents from the paycho-motor cortex; moreover, the centres of swallowing, respiration, vomiting, and all the centres in the bulb are Influenced by Impulses from the tertlary taste and smell centres from which nervous tracts arise, and wholly or partially terminate in the tegmentum balbi.

The sensory division of the fifth and the superior laryngeal nerve stand as sentinels to the alimentary and resplratory tracts, and when stlmulated by chemical or mechanical agents excite appropriate reflezes for 
the preservation of the individual, and these reflezes are instinctive and untaught, but nevertheless involve an associated co-order in vast eystems of efferent motor neurones in the bulb and cord ; Inhibition of one group, impulsion to another, aceording to the purpose required; the same groups of neurones thereby bringing about entirely different actions according to the nature of the stlmulus, just as we know occurs in the purposive spinal reflexes, only in a more complex way. But this can only be accounted for in the case of sucking, crying, laughing, and the expression of the primitive emotions, as witnessed in animals, children, and all races of men, by accepting Darwin's theory of the evolution and transmission of an associsted habit serving some useful purpose in the preservation of the individual or the species. But integrative action or co.ordlnation, as Bherrington's important experlments on the spinal animals show, is effected by neurones of issociation linking up the spinal motor neurones in such a way that they discharge or inhlbit innervation currents from the spinal motor neurones to groups of antagonistic muscles in such a way that the action in response to the stimu. lus is most apprcpriate for the preservation of the animal or the ppecles. In other words, in response to all stimuli whlch are of fundamental im. portance to the life of the Individual or the preservation of the species, nervous torce will always tend to flow along the path formed by associated habit ancestrally Innate, and therefore atable, by a transmitted preorgar1 zed mechariem. Darwin, alded by the Investlgatinns of Dondere, surported the view of Silr Charles Bell that the use of the orbiculatis palpcbrarum was to com. press the ejeball and protect its delicate 8 tructure whenever the chest is vlolently contracted (vide Flg 4). He, mor eover, points out that

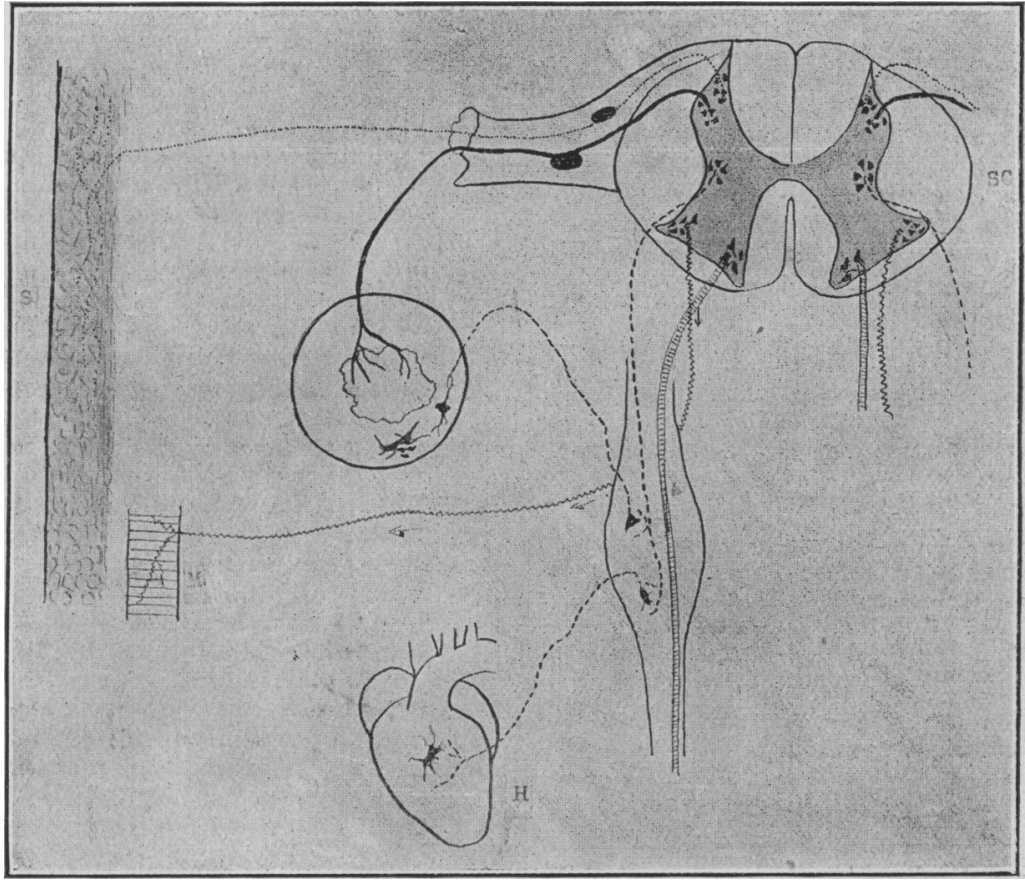

Fig 6.-A diagram to show the various functional groups of neurones in an upper thoracic spinal segment. The most onterior gruup is sumatic; the group in the Jateral horn is respiratory somatic : the group of small cells at the junction of the ar.terior and posterior horns (intermedio lateral) is viscero-vascular. There-are thus three groups of effdrent neurones. There are two groups represented here of sensor in fig 7 and 8 It will be ofserved that although the arrangement of the column of cells is much more complex in the bulb, the same segmental functional groups

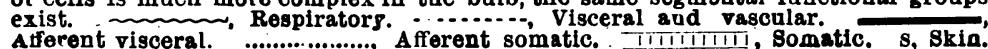
H, Heart. sc, spinal cord. M, Muscle. partial, but continuous leakage of nerve energy along preorganized paths of associated actlon expressive of a pong-continued frame of mind, and therefore rudimental In early infancy.

Darwin points out that the py ramidales of the nose are less under the control of the wlll than the others, and central fasclae of the frontal muscle; these latter fasclas up the inner ends of the ejebrows and wrinkle the nize as the expression of grlel or anxlety (vide Fig. 5).

We thus see that there is a great deal of truth in Sir Well's statement:

The organ of breathing in association with the heart is the Instrament of expresslon, and ts the part of tha frame by tbe to us.

Agaln:

That what the eye, the ear, and the heod is to the mind in ex 3 iting those Ideas whloh have been sppolnted to correspond with the qualitites of the materlal world, the organs of the bresst are to the development of our iff dotior $\mathrm{s}$.

Henle on the natural history of the Eigh in hls $\mathrm{An}$ thropobigiche Vort,$\ddot{a}_{s} e$ calls attention to the fact that thire is a contest between the otriped skeletsl muscles of respiration and the unstriped muscles of the lungs which seek to narrow the bronchlal tabes. "In the normal state the former easlly conquer but under other conditlons they elther conquer with diff. culty or are dtfeated " (James).

The contrasted emotlons express themselves in sim?larly contrastedwise, by spasm and paralyels of the unstriped muscles and for the mos: part allke in all the organs which are provided with the $m$ as arteries, ckIn and bronchial tubes. The contrast when infants scream loudly from hunger or pain the circulation is affected, and the eyes tend to become gorged with blood; consequently the muscles surrounding the eyes are strongly contracted as a protective; this action in the cjurse of many generations has become firmly fixed and inherited, but when with advancing sears and culture the habit is partially repressed, the muscles around the eyps still tend to contract whenever some slight dlstress is felt; although under the control of the will, a certain amount of escape of nerve energy along the path of assoclated habit cannot be avoided. "There is no art to find the mind's complexion in the face" is well illustrated by the action of the depressor anguli oris; its action, signalized in popular languge as "do $\mathrm{xn}$ in the mouth," is indicative of mental depression or suppressed griel; In the child, just before it is going to.burst out crying, or when it is trying to suppress u fit of crying coming on, the drawing down of the mouth by this muscle is especially noticeable. The wrinkling of the forehesd and drawing down of the mouth, when constantly present, Indicate prolonged sorrow and suppressed griel. They may be looked upon as an involantary, among the emotlong is generally expressed by dividing them in to exclting and depressing onea. It is a remarksble fact that the depressing emotions like f $\mathrm{ar}$, horror, and disgust, increase the contraction of these s mooth muscles, whilat the exciting emotions like joy and anger make them relar. If there are pulmonary vasomotor fibres then these are constricted with the bronchlal tabes, and a feeling of insufficient breath and oppression occurs, and the Ineffective actlon of the diaphragm - obtrades itself upon conscionsness by the fact that the externsl voluntary chest muscles have to be called to its ald to draw a deeper breath, and this is the sigh which we know is associated with anxiety and slaks of mental depression. It is quite possible that impules from the higher centres ln the braln may Inhibit the insplratory centre, and bring about the same effect as is prodaced by stimulation of the superior laryngeal nerve, causing thus an unpleasant sensation of resistance to the movements of ineplration which is relleved by $a$ slgh.

I have alreajy in my first lecture referred to fear and the physlcal phenomena assosiated with that emotlonal 
state: ' Let us conslder the opposlte condition-anger-and see how far our knowledge of the functlons of the eystems referred to 'In the dragram (Flg. 6) serve to explain the phenomena of fear and anger. Darwin sajs Shakeepeare sums up the chlef characteristlcs ol rage as follows:

In pesce there's nothing so becomes a man As modest stillness and humility ;

Bat when the blast of war. blows in our ears Then Imitate the action of the tiger.

Stiffen the sinews, summon up the blood, Then lend the eje a terrible aspe ct;

Now set the teeth, and stretch the nostrils wlde, Hold hard the breath, and bend up every fplrit

To his full helght! On, on, you noblest Eoglish.

Henry $V$, Act lii, Scene 1.

Bell points out that the muscles of the arms in man and the forelegs ' In feroctous bi utes (the tiger) belore they spring must have a fixed point d'appui, consequently the chest walls must be fixed, and to give the forelimbs their fullest power it must be ralsed and expanded as well as fixed.

Summon up the blood; thls can only be done by inhlbitlon of vaso-constrictor influence on the kkin and muscles.

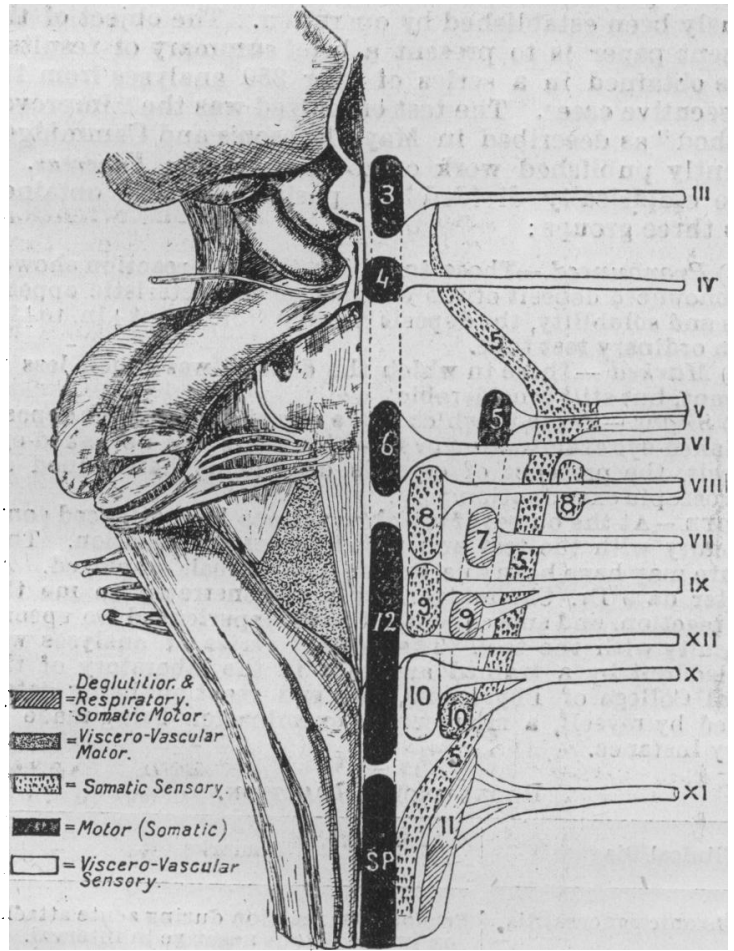

Fig. 7. - This diagram should be associated with Figs. 6 and 8 . The important nuclei of the cranial nerves are functionall groupea as in a spinal thoracic segment. It will be observed tha ferminate in a column of cells continuous with the posterior horn the three motor groups, as pointed out by Kappers, do not retain the definite alignment found in the thoracic spinal cord.

Set the teeth hard and stretch the nostrils wide: lexd the eye a terrible aspect, will be effected by an incresse of innervation currents to all the muscles supplied by the facial and motor filth. Hold hard the breath is effected by a discharge of Innervation currents to all the muscles supplied by the Inspiratory column of cells. Stiffen the sinews necessitates a discharge from the whole motor somatic column of cells. In all these expresslve actions of rage we do imitate the tiger before it springs. Can we explain the nervous mechanism which leads to this instinctive actlon showing antagonism between the action of the striped and unstriped muscle? In the doreal region of the spinal cord where. the original segmental arrangement is preserved we find somatic, respiratory, and viscero-vascular nuclei represented. In the normal and quilescent non-emotional state an equable reflex tonus by afferent stimuli is maintained in somatic, respiratory, and viscero-vascular muscle, but under the influence of the emotion (rage) there is a sur. charge of nerve potential flowing out through the somatic and resplratory eystems of neurones, consequently there may be a dralnage away of the normal flow of potential by the viscero-vascalar neurone 3 and a vascular dilatation will occur; or the vascular dilatation may be expla'ned by antidromic discharge along the posterior: roots, which may, as Bayliss's experiments prove, lead to vaso-dilatation. But how are we conscious of this change in our bodily state? By the afferent impressions to the brain from the ekin, muscles, and viscera, but mainly the two former, and these : impressions will arise in the: whole column of sensory cells, somatic and visceral, from the top of the filth nucleas to the end of the spinal cord (see Figg. 6, 7, and 8).

Before reaching the seat of consoloueness, however these impressions will all be projected into the thalamic grey matter, where a fresh relay of neurones occur. But the thalamic region is also a statlon for recelving Impressions from the specisl senses-hearing, slght, tonch, taste, and smell-where relay neurones occur by which, the several speclal sense stimuli are convesed to definite regions of the perceptive cerebral cortex. The thalamus thus may be the great subconscions centre for the elsbcrstion and co-ordination of eensory impressions derived from organic changes in the bcdy and those brooght by

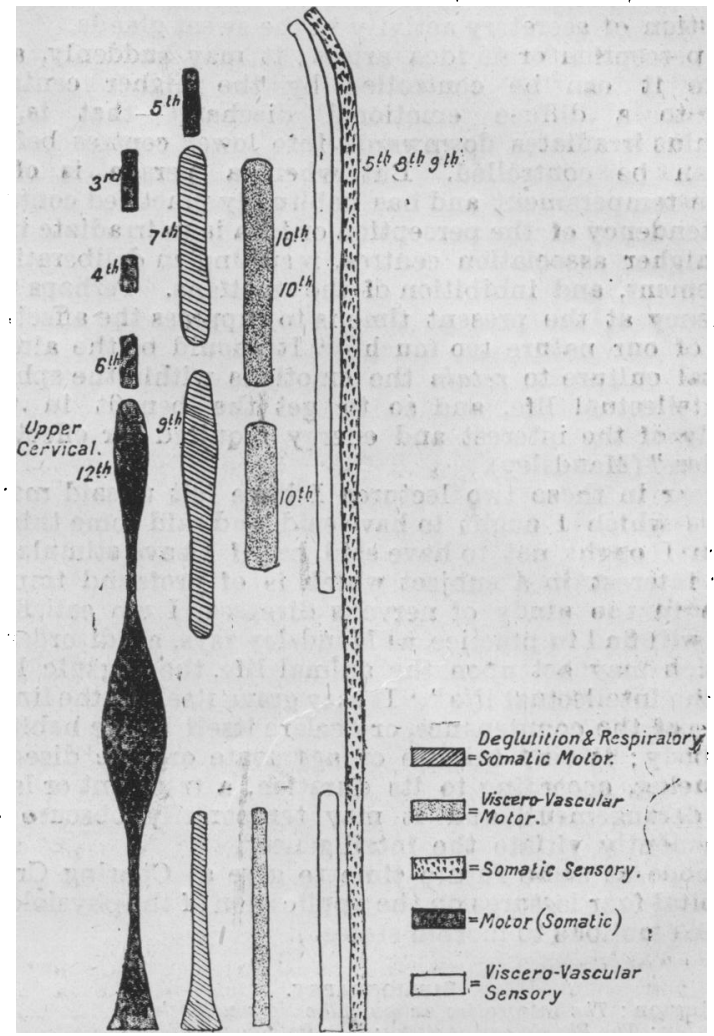

Fig. 8. -This rough diagram was made during the lecture. It shows the relative positions of the five systems of neurones from the top of the medulla to the end of the thoracic spinal cord. The respiratory, the viscero-vascular motor, and the viscero-vascular respiratory, the viscero-vascular mo.or, and the viscero-vascular, which is entirely coanected with the life of relation and in association with vision plags a predominant part. In order that the diagram should not occupy too much space. tne twelve spina thoracic segments have been much curtailed relatively to the remainder.

the speclal senses from the material world around. The thalsmus is connected with the corpus striatum, and it is possible that both the basal ganglia may be primary centres of emotional discharge to the lower centres.

Every thought tends to activation, and thoughts based upon the revival of memorles of past experiences are more or less suffased with affective tone, according to the nature of the experience and the temperament of the Individusl. There wlll thus be a tendency to revival of the physical concomitants (emotions) of that affective tone. It does not require a delicate instrument to prove the trath of this statement in mang instances, for we know that the recollection (revlval in consciousness) of a great sorrow or injustice plll awake sometimes a more violent emotional discharge than actually occurred at the time it was experienced. The experlments of Féré, Tarchanoff, Veraguth, and Jung and Petersen tend to support this conclusion; these observers have shown that if the body of an Individual is 
introduced Into the clrcuit of a galvanometer through whlch a weak, current is passing, and the resiletance, being 50 : arranged by, means of a rheostat as to enable them to bring the needle to zero on the scale, parchical conditions will lead to a deflection of the needle of the galvanometer. The : Inference is that the peychical change-produces some physical change by which the cament passes less readily or more readily through the bady. The results previonsly obtained by Fére and Tarchenoff have been corroborated and further elaborated b) Veraguth, who found that if an Individual introduced Into the olrcult, be read to, deviation of the mirror is noted when passages associated with emotional tone are reached. Or. If a series of unrelated words is pronounced by him, the words connected with some emotlonal complex prodwce an effect on the galvanometer, while indifferent werds.have no effect. He is unable to explain the changes in resistance. Jung and Petersen, who have repeated and elaborated the above experiments and applied the method of : Investigation to cases of dementia praecox, conclude that the change in resistance is due to the relative condition of secretory activily in the sweat glands.

A perception or an Idea arlses; it may ouddenly, and before it can be controlled by the higher centres, lead to a diffuse emotional discharge-that is, a stimulus Irradiates downwards into lower centres belore it can be controlled. But when $a$ person is of 8 stable temperament and has habltually practised control, the tendency of the perception or ides is to Irradiate Into the higher association centres, resulting in deliberation, judgement, and inhibition of the emotions. Perhaps the tendency at the present time is to suppress the affective side of our nature too much. "It should be the alm of mental culture to retain the emotlons within the sphere of Intellectual life, and so to get the benefit in the supply of the interest and energy required for effective volltion" (Maudsley).

I fear in these two lectures I have left unsald many things which I ought to have sald, and eaid some things which I ought not to have said, but If I have stlmulated your interest in a subject which is of profonnd importance in the study of nervous diseases, I am satisfied. You will find in practice, as Maudsley says, a "dlsordered emotion may act upon the animal life, the organic life, and the intellectual life." "It may grave itself in the lineaments of the countenance, or declare itself in the hablt of the body; it may initlate or aggravate organic disease, producing, according to Its duration, a transient or lasting derangement, and it may temporarlly obscure or pernanently vitiate the intelligi nce."

I hope at some future time to glve at Charing Cross Hospital four lectures on the applicstion of the physlology of the emotions to morbld states.

BIBLIOGRAPHY

Maudsley: The Physiology of Mind

Ribot: Les Sentiments

James : Principles of Psychology.

Bain: Mental and Moral Science.

Bellitsir Charles: The Anatomy of Expressiox.

Vergt: Les Emotions.

on.Monaliow : Gehirn Pathologie.

(1) Emotions.

Dictionnair

Pagano: Archives Italiennes de Biologie, 1906.

chäfer: Textbook of Physiology. Articles: Respiration, Starling Circulation, $\mathbf{L}$. Hi

Kappers, Ariens: Woitere Mitteilungen bezüglich der phylogenetishen Verlagerung der motorischen Hirnnervenkerne. Der Bail des Autonomen Systemes. Folia Neuro-Biologica, Bd. 1, Nr. January, 1908 .

ON March 19th the Maryland State Senate paseed a Bill prohibiting Christian Scientists or faith-healers from practising in Maryland without the diploma of regular physicians. The Bill has already passed the House.

THE American Therapeutic Society will hold its ninth annual meeting at Philadelphia on May 7th, 8th, and 9th Among the features of the meeting is a "symposium" on diseases of the vascular system. Among the subjects to be discussed are: The pharmacology of heart stimulants, by Dr. Horatio C. Wood, jun. (Philadelphia); venesection in diseases of the heart, by Dr. Judson Daland (Philadelphis); and some conditions requiring caution in the use of digitalis, by Dr. Alexander D. Blackader (Montreal). Another feature will be a "symposium " on the treatment of tuberculosis.
THE CLINICAL VALUE OF THE PANCREATIC BEACTION IN THE URINE, BASED ON OVER 250 ANALYSES.

Bx CHALMERS WATSON, M.D., F.R.C.P.E, ASSISTANT PHYSICIAN, ROYAL IMFIRMARY, BDINBORGR.

IN recent years the clinical researches of Mayo Robson and other observers have directed attention to the comparative frequency of serlons organic disease of the pancreas and to the various clinical tests which assist in its recognition. More particularly, attention has been directed to the value of the pancreatic reaction in the urine, a test devised by Cammidge, whlch has proved in Mayo Robson's experience of great value in diagnosila Thls test, first described by Cammidge in 1904, has been elaborated and improved, and in 1908 is again advanced by its originator as a valuable diagnostic method, after an experience of 800 analy ses.

My interest in this subject was aroused in the course of the autumn of Jast year through the admission to Sir Thomas Fraser's wards, then under my care, of a case of chronic pancreatitis, in which this diagnosis had previously been established by operation. The object of the present paper is to present a brief summary of results $P$ have obtained in a serles of over 250 analyses from 120 consecutive cases. The test employed was the "Improved method "as described In Mayo Robson's and Cammidge's recently published work on Diseases of the Panoreas. I have empirically divided the positive results obtained into three groups :

(a) Pronounced. - Those in which the ond reaction showed a pronounced deposit of the orystals of characteristic appesrance and solubllity, the deposit ranging from about $\frac{1}{4}$ in. to $\frac{1}{2} \ln$. in an ordinary test tube

(b) Marked. - Those in whloh the deposit. was much less in smount, but still considerable.

(c) Slight. -Those in which there was either a slight deposit on naked-eye examination or In which there was no naked-eyedeposit, the presence of crystals only being determined on: mioroscoplo examination.

NoTk. - At the outset of my observations I experienced some difficulty with the test and falled to get any reaction. Thls fallure may have been oue to faulty chemicals emplojed. At 8 later date Dr. Cammidge kindly demonstrated to me the end reaction, and sube equently I have experienced no special difficulty with the test. The present serles of analyses was carried out by a trained assistant in the laboratory. of the carried out by a trained assistant in the laboratory of the
Royal College of Physiclans, the end reaction being deterRoyal College of Physiclans, the end reaction being deter-
mined by myself, a mloroscopic examination belng made in. every Instance.

Pronotnced Reaction.
Clinical Diagnosis.

1. Chronic pancreatitis Pronounced reaction during acute attacks on two occasions negative in interval.

2. Acute pancreatitis Operation: Incision and drainage; cholecystenterostomy (Mr. Caira), Reaction negative when patient was discharged

3. Acute suppurative cured. Pancreas showed the naked eye and appendicitis and microscopic appearances af acute pap-

peritonitis
4. Malaria (aestivo- Jaundice with pronounced epigastric autumna]) . tenderness. Reaction became negative cincidently with recovery from jaundice.

5. Pneumonia $\quad . . \quad$.. Died. Pronounced reaction three dayg before death; reaction negative on day of death. Pronounced arterial sclerosis. No post-mortem examination.

6. Chronic bronchitis, Pronounced reaction on three occasions.

7. Alimentary glycosuria Marked diminution in the degree of reand constipation

pronounced reaction associated with glycosuria. Extensive maligna
was revealed at the operation.

9. Gall stones in common Reaction negative on two occasions in bile duct on day before operation (Ianuary 10th) reaction became very marked and patient died on fourteenth day. Pancreas showed the naked eye and microscopic appear ances of recent inflammation.

10. Exploratory lapar- Palpable tumour in reeiton of pancreas. Fronounced pancreatic reaction with trace of glvcosuria; at the operation pancreatitis.

11. Pregnancy; seventh Pronounced reaction assoclated with glyarterio - sclerosis. Man, aged 48. Incapacitated from work. 